Cahiers $d u$ MONDE RUSSE

\section{Cahiers du monde russe}

Russie - Empire russe - Union soviétique et États indépendants

$51 / 2-3 \mid 2010$

Dynamiques sociales et classifications juridiques dans l'Empire russe

\title{
Rethinking elite integration
}

The Crimean Murzas and the evolution of Russian nobility

Repenser l'intégration des élites : les mourzas de Crimée et l'évolution de la noblesse russe

\section{Kelly O’Neill}

\section{OpenEdition}

\section{Journals}

Electronic version

URL: https://journals.openedition.org/monderusse/9195

DOI: $10.4000 /$ monderusse. 9195

ISSN: $1777-5388$

\section{Publisher}

Éditions de l'EHESS

\section{Printed version}

Date of publication: 9 September 2010

Number of pages: $397-417$

ISBN: 978-2-7132-2315-0

ISSN: $1252-6576$

\section{Electronic reference}

Kelly O'Neill, "Rethinking elite integration", Cahiers du monde russe [Online], 51/2-3 | 2010, Online since 26 October 2013, connection on 03 September 2022. URL: http://journals.openedition.org/ monderusse/9195 ; DOl: https://doi.org/10.4000/monderusse.9195

This text was automatically generated on 3 September 2022 


\section{Rethinking elite integration}

The Crimean Murzas and the evolution of Russian nobility

Repenser l'intégration des élites : les mourzas de Crimée et l'évolution de la noblesse russe

Kelly O'Neill

\section{AUTHOR'S NOTE}

Research for this article was funded by the Fulbright-Hays Program, IREX, and the Davis Center for Russian and Eurasian Studies at Harvard University. Sincere thanks go also to my anonymous readers and to the editors at Cahiers du Monde russe.

1 In tsarist Russia the nobility, like the empire itself, was a multiethnic entity. Though scholars began puzzling over the implications of this heterogeneity long ago, the "new imperial history" elaborated over the past two decades has inspired scholars to look with fresh eyes at the meaning and function of the soslovie system. ${ }^{1}$ This growing body of work has challenged the traditional conception of a relatively static four-tiered hierarchy of legal estates and begun to unpack an array of neglected social categories and status groups embedded within that hierarchy. Many of those groups inhabited the borderlands. In fact, re-writing Russian history as the history of an empire has opened new terrain for testing the boundaries of social categories and their utility as tools of empire building. Most important for the purposes of this article, recent scholarship has demonstrated that the relationship between imperial officials and indigenous elites often determined the character and efficacy of tsarist rule in newly acquired territories. ${ }^{2}$

Indigenous elites certainly stood out as potentially valuable assets in a resource-starved environment. Their fates within imperial society were, however, as varied as their backgrounds. Some served as temporary proxies for Romanov authority; others became permanent fixtures in regional governance. Some were amenable to cooptation; others resisted assimilation in any guise. Efforts to push the discussion of elites beyond the constrictive language of submission and resistance have led into the more nuanced 
terrain of negotiation and accommodation. Parsing the dynamics of such processes is no easy task, but it has proven to be a productive way of uncovering bits and pieces of the lived experience of imperial rule. ${ }^{3}$

3 The more we learn about borderlands the less satisfying the geography that often circumscribes discussions of non-Russian populations and the institutions that governed them. Elite integration was a core element of the relationship between center and periphery, but it had an equally important latitudinal dimension. Many imperial practices had a similarly dual nature. In fact, one of the great strengths of Russian empire building through the early nineteenth century was its ability to balance attempts at standardization with the formal acknowledgement of regional particularities ranging from the Lithuanian Statute and shari'a law to the autonomous status of the Grand Duchy of Finland. This article does not argue against the core-periphery approach that has revealed so much about the complexities of imperial rule. Instead, it proposes a complementary framework for studying elite integration. The soslovie system, like the empire itself, was not simply a set of vertically ordered relationships linking the court to carefully defined cohorts or, in the case of the dvorianstvo (noble estate), of ranks and ribbons linking the tsar to an individual servitor. It was a social and cultural construction as well: wealth, marriage, lineage, service, education, and cultural background tempered the notion of nobility as a purely ascribed status. The scholarly debate over the extent to which the dvorianstvo constituted a self-aware corporate entity is alive and well, but the histories of elite integration suggest that the ennoblement of borderland figures engendered a reconceptualization of the implications and accessibility of noble status throughout the empire. ${ }^{4}$

This process had roots in one of the most famous decrees of the eighteenth century. Peter III's decree proclaiming the emancipation of the nobles from obligatory service in 1762 inaugurated a century of rumination on the nature of the nobles' suddenly vague relationship with the state. Catherine II's provincial reform (1775) and charters to the nobility and towns (1785) then created a new architecture of governance. She sought to harness the authority and (assumed) expertise of emancipated nobles by assigning a host of judicial and social functions to the noble assembly in each province. While the impact of these reforms in individual provinces awaits further study, many scholars agree that in interior provinces they led to the divergence of the provincial bureaucracy from the provincial nobility rather than to a dramatic redefinition of the meaning and function of the dvorianstvo. ${ }^{5}$ The parallel acquisition of tens of thousands of Polish szlachta, Cossack starshyna, Tatar murzas, and Georgian tsarevichi, coupled with the implementation of Catherinian policies, made the non-Russian borderlands unexpected engines in the evolution of the nobility.

5 This evolution has lingered in the shadows of work done on the implementation of Russian rule in the borderlands. For more than a century and a half, the majority of scholarly works presented elite integration as the process (contentious or otherwise) of drawing new populations into an existing body. According to this scheme, a manifesto issued in the aftermath of annexation or conquest declares the elite of the new territory the equivalent of Russian nobles. In time a committee is set up to oversee the pro forma ennoblement process, and members of the local elite scramble to meet the criteria cobbled together from the terms of the 1785 charter and the annexation documents. Imperial officials initially appear willing to accept the local definition of social categories, but as the years pass and the security of the frontier improves they become 
less willing to accommodate regional particularities. In the end, those who meet the criteria laid out in the 1785 charter assimilate and serve the interests of the empire. The rest sink into the differentiated but distinctly unprivileged mass of the peasantry, and the impact of any compromises made along the way is confined to the status of the particular borderland elite that elicited them.

The case of the Crimean murzas suggests that elite integration was not as localized or narrowly defined a process as it might appear. The Crimean murzas were a small but significant elite group. ${ }^{6}$ Baltic Germans generally outranked them and Polish szlachta surely outnumbered them, yet the Crimean murzas exercised the minds of imperial officials for nearly six decades. There is good reason for this. The murzas were a diminutive population - never more than 500 at a given time - but they were Muslims in an era of religious toleration, former vassals of the sultan in the age of Russian-Ottoman rivalry, and heirs to steppe traditions in the midst of Russia's attempt to reinvent herself as a European state. Determining whether and how a murza might become a dvorianin (nobleman, pl. dvoriane) therefore had wide-ranging logistical and ideological implications.

The rapid chronological progression from annexation in April 1783 to Catherine's decision to apply the terms of the provincial reform in February 1784 and the charter to the nobility in 1785 pulled the new province and its Muslim elite into broadly conceived transformations of the administrative and social order. ${ }^{7}$ During the next fifty-five years the rules, the stakes, even the meaning of noble status, were in flux across time and space. Throughout this period the majority of Crimeans argued that they enjoyed the privileges of Russian nobility by virtue of being murzas, and they therefore sought confirmation of the equivalency Catherine herself had drawn between murzas and dvoriane in the early days of Russian rule. Emperors, governors-general, senators, and ministers weighed in on the issue, and three commissions convened to sort through the murzas' petitions and documentation. By 1827, a total of 295 murza petitions gained the approval of provincial officials, and most everyone involved considered the matter resolved. ${ }^{8}$

In 1840 however, a State Council decision struck all but forty members of the Muslim elite from the noble register, drastically altering the landscape of nobility in Tavrida. They were removed in part because the regime saw confession and ethnicity in increasingly politicized terms - being Muslim and Tatar made it difficult to gain admittance to the noble estate under Nicholas I. But assessing the fate of the murzas solely from the vantage point of the Crimeans themselves masks a broader significance of their story. Officials in St. Petersburg fretted over the ennoblement process unfolding in Simferopol because they knew that the boundaries separating elite entities - Russian and non-Russian, ranked and unranked - were porous, and that even seemingly localized policies had empire-wide implications. Thus as much as the integration of Crimean murzas reveals about a particular iteration of the relationship between core and periphery, it also suggests that we rethink the geography of social categories and the dynamics of the process through which officials and elites continually curated noble society. 


\section{The trouble with Rodoslovnye Knigi}

9 The dvorianstvo was never homogeneous, but it might have been the most well-ordered stratum of Russian society. The Table of Ranks instituted in 1722 lent an air of credibility to the notion of a merit-based rank system and seemed to signal a shift away from traditional honor-based hierarchies toward principles of rationalization and bureaucratization. But that was only the beginning. By mid-century, the dvorianstvo was in the midst of a sea change. With Tsar Peter III's 1762 emancipation decree the figure of the retired gentleman whiling away his hours in quiet contemplation or self-motivated industry on his estate was no longer confined to the realm of (foreign) fiction. The legislative assembly of 1767 provided nobles with a venue for airing both grievances and ideas about the regulation and function of social status, and a series of decrees in 1775, 1778 , and 1785 redefined the noble assembly as a semi-autonomous entity endowed with specific privileges, powers and obligations. ${ }^{9}$ Catherine's goals were to ensure the sovereign's monopoly on prestige, standardize the boundaries of noble authority, and foster what she saw as the organic connection between estate owners and state servitors. By some measures, her policies succeeded. In fact, one of the striking things about the dvorianstvo is its apparent demographic consistency: for eight decades the noble population hovered just under one percent of the general population. ${ }^{10}$

Yet distinctions were built into the very foundations of noble society. Whatever their location or concentration, Catherine subjected dvoriane to an Enlightenment project concerned with rationalizing, ordering, and documenting. Inscription in the rodoslovnaia kniga (noble register) for example, required proving one's rightful place in a six-tiered hierarchy that tethered noble status to service record or lineage. ${ }^{11}$ The true innovation of Catherinian policy, was that it balanced this form of stratification with the generation of cohesive local entities. It held dvoriane responsible for presenting satisfactory documentation of their 'worthiness' in the provinces where they resided or owned estates. Henceforth nobility would be managed at the provincial level according to rules and procedures implemented in uniform fashion across the empire. ${ }^{12}$

11 Within a short time, the Heraldry department of the Imperial Senate shored up the significance of provincial identity by producing a new symbolic language in the form of coats of arms and dress codes. The socio-spatial ordering of the noble population became entrenched enough that foreign observers were able to read crowds as though they were reading a map. During Catherine's famous journey to the Black Sea in 1787, for example, the Prince de Ligne observed that "the provinces of the East [wore] brown and gold and silver" to royal suppers, while "the others [wore] red and sky-blue." ${ }^{13}$

This decentering of noble identification is crucial to understanding the dynamics of elite integration in Tavrida. Despite the relative stability suggested by the annual aggregate noble population, at the provincial level noble populations throughout the borderlands fluctuated (in some cases dramatically) through the middle of the nineteenth century (Fig. 1). ${ }^{14}$ 
Figure 1. Change in the noble population of select provinces, by region

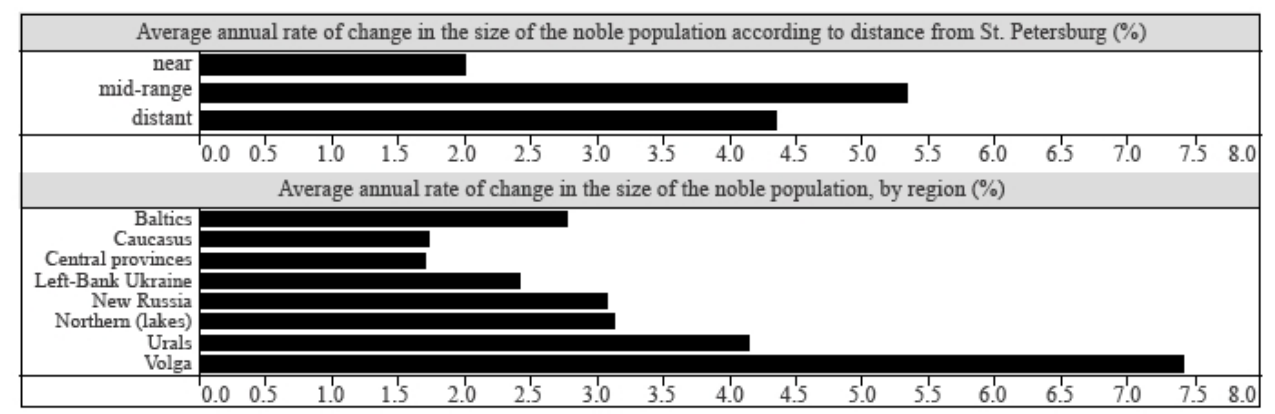

13 Numerous variables contributed to this relative volatility, but some of the most important were connected to the challenges of managing and eventually integrating non-Russian, non-Orthodox elites. Russian officials serving in Tavrida were acutely aware of the value of harnessing the social capital of the murzas and beys. "[We must] train them imperceptibly in our customs, our amusements, the pleasure we take in our lives and even in our work," wrote one Tavridan noble:

This is all the more important because among the murzas there are those who descended from Chingis Khan, and Your Excellency well knows in what high regard and with what level of respect they are therefore held by the Muslim people. Whether they are indigent or legitimate heirs is immaterial - it is enough that the crowds believe them... Their devotion to Russia, their acclimation to our way of life secured, they might in future prove very useful in political, military and trade relations with Turkey. ${ }^{15}$

14 Over the years Russian officials and their Muscovite counterparts had accrued substantial experience in the art of incorporating Volga Tatars, Baltic Germans, and Polish magnates into imperial society and the integration of the Crimean murzas might have been just another iteration had it not been for the 1785 charter. The charter, with its insistence on standardizing the definition and ascription of nobility across the empire, ran against the grain of Catherinian policy in newly acquired territories. In Crimea for example, Catherine (along with Prince Grigorii Potëmkin, governor-general of New Russia among other things) found it expedient to grant privileges to her new subjects and to assure them that Russian rule would not entail a radical revision of the social hierarchy or cultural institutions. The annexation manifesto thus promised, in return for the Tatars' loyalty, "to allow each [subject] all the rights and privileges enjoyed by a Russian of his status (sostoianie)" and to protect the faith and laws of the Crimean population. Just a few months later Catherine exempted the Crimeans from the poll tax and military recruitment - two of the most onerous burdens imposed on the Russian population - and later announced that the "worthy" among them had the right to acquire officer rank and serve in the provincial government. ${ }^{16}$ While it might have seemed obvious that the beys and murzas were the natural counterparts of the dvoriane, Catherine said nothing about ennoblement; nor did she ascribe status to any element of the Crimean population.

A decree issued in February 1784 seemed to change all of that. The document allowing "Tatar princes and murzas to enjoy all the privileges of the Russian nobility" is often cited as evidence of the integrative capacity of the dvorianstvo and the official ennoblement of murzas from Bahçesaray to Kazan. ${ }^{17}$ It is true that it opened a formal space for Muslim elites. As a result, nearly 5,000 murzas from 177 clans inscribed their 
names in noble registers by the time Catherine died and by 1834 the registers of 15 different provinces included murzas. ${ }^{18}$ However, the 1784 decree did not actually ascribe noble status to the murzas. It allowed them to petition for it and instructed officials to compile special lists of those murzas "worthy of the privileges granted to the Russian nobility." In other words, it upheld the equivalency drawn between dvoriane and Tatar elites.

Elsewhere, Russian officials had used just such equivalencies to the empire's advantage. In the provinces of Left-Bank Ukraine (the Hetmanate's autonomy was abolished in 1764), they initially incorporated local traditions, accepting patents from Russian and Polish rulers, evidence of ownership of settled land or Cossack starshyna status as acceptable proofs of elite status. When written documentation of any kind proved scant, officials accepted the sworn testimony of peers to attest to the lineage of each applicant in accordance with the requirements of the 1785 charter. By 1790, over 20,000 petitions for noble status from this region alone won approval on these grounds and although this number represented less than two percent of the provincial population, it was over 20 percent of the (male) noble population of the empire. Even more important than the ethnic and regional imbalance was Catherine's sense that her ennoblement procedures had been manipulated to corroborate claims based on foreign criteria of noble status. The Senate promptly demanded a review and by 1795 removed over ten thousand individuals from the noble registers. ${ }^{19}$

Over the next few years the government repeatedly reminded noble assemblies throughout the empire that their job was to recognize noble status, while the tsar alone had the authority to confer it. In order to drive this point home, in February 1803 Alexander decreed the sworn testimony of peers insufficient proof of noble status throughout the empire. ${ }^{20}$ Ennoblement henceforth required thorough documentation. The impact of this decision was broad and immediate. French émigré families, for example, had no access to personal or official archives in France, and even wealthy, entrenched Russian nobles were often plagued by problems of insufficient documentation.

In a province like Tavrida where the vast majority of would-be nobles offered only the testimony of peers as proof of their descent from elite clans, this was potentially catastrophic. Aware of the misfortunes of his Ukrainian peers, Mehmet bey şirin, provincial marshal and chief of the most influential Crimean clan, led the Crimean murzas in a spirited defense of their status as a discrete, autonomous entity within the Russian elite. In an elegant exposition of this idea (composed in French, no less), şirin insisted that the privileges of the Crimean murzas were indisputable regardless of whether or not they inscribed their names in the noble register. Grigorii Potëmkin's successor Platon Zubov and Catherine herself had confirmed these privileges as recently as September $1796 .^{21}$

In an effort to maintain order, Governor G.P. Miloradovich convinced the tsar to convene a special "commission on nobility" to determine once and for all the status and composition of the Crimean elite. Provincial Marshal E.S. Notara, though hardly a supporter of murza interests, expressed his approval of the commission's agenda. "The Tatar beys and murzas of this province do not simply belong to noble society," he admitted to the minister of justice, "they constitute it." 22 


\section{From Land to Lineage} status to re-petition according to the terms of the 1785 charter, and three years later Alexander I extended this opportunity to almost all odnodvortsy, including Lithuanian murzas and the murzas of Kazan province. ${ }^{25}$ The widening distribution of landownership rights was appealing to many of the influential figures who remained convinced that there was a strong correlation between landownership and loyalty to the regime. In his memoir on Tavrida for example, writer and statesman Ivan Matveevich Murav'ëvApostol insisted that the only surefire way to guarantee stability in the province was to cultivate a love of property among Crimeans. ${ }^{26}$ altogether. In Tavrida, the dissociation of landownership and noble status theoretically saved provincial officials the embarrassment of ennobling hundreds, perhaps thousands, of poor, uneducated landowners with no traditional standing in Crimean society. In practice however, a crucial safeguard remained in place. Individuals applying for noble status solely on the basis of landownership could only be inscribed in the register if their peers expressed no doubt about their "worthiness" (dvorianskoe dostoinstvo). In other words, members of the local elite, assembly deputies, and particularly marshals, could protect their collective and their personal interests by confirming or denying the legitimacy of a petitioner's qualifications. ${ }^{27}$

Among Crimeans, those qualifications derived almost exclusively from lineage and clan affiliation. Owning land in the khanate did not convert a Tatar peasant into a murza. By contrast, the status of a murza's clan and his own position within that clan played a key 
role in the resolution of disputes over ownership and inheritance brought before Russian courts, which had pledged to respect and uphold local customs and Islamic law. In 1823 for example, the Evpatoriia district land court and Tavrida civil and criminal chambers ruled that Abdişa bey Mansur could not legally alienate a 15- desiatina parcel near the village of Bakal on the grounds that the land was part of the Mansur beylik (the land controlled by a major clan). According to Crimean law, as bey (chief of one of the elite Crimean clans) Abdişa had the right to use, but not to alienate land that belonged to the clan. ${ }^{28}$

Murzas who took note of such decisions successfully tailored their arguments, grounding them in Crimean custom rather than Russian law. Thus in 1847 Neitşa bey Iaşlav informed the noble assembly of his right to inherit the lands held by his forefathers without presenting documentation of ownership for the simple reason that "the custom was for land to be inherited by the eldest of the clan. There was therefore no need for deeds of sale," Nietşa explained, though he took care to point out that according to the (Russian) provincial survey of 1801 the Iaşlavs had held the land in question "from ancient times and without challenge." ${ }^{29}$

Mansurs and Iaşlavs were well-placed to advance such arguments, for they sat near the top of the clan hierarchy that structured the elite of the former khanate. The Crimean definition of nobility held that elite social status depended not on service or proximity to the khan, but rather on the prestige and power an individual or his clan accrued independently. This definition of elite origins presented a fundamental contradiction to the formal Russian insistence that all prestige and power derived from the tsar. While theoretically Georgians, Poles, Ukrainians, Germans and Tatars could all become Russian nobles, they could do so only by acknowledging that their privileged status was a gift rather than pretending that those privileges represented a curb on the sovereign's monopoly on social authority.

The number and alignment of clans that composed the ruling elite of the khanate varied over time, though the main contours remained more or less constant. The khan, his sons, and other members of the Giray dynasty occupied the top level of the hierarchy, followed by other descendants of the Chingissid house. The most powerful clans, known as the karaçi, included a varying combination of the şirin, Mansur, Sicuvut, Argin, Kipçak and Iaşlav clans. Next came the 'princely' clans, many of whom traced their origins to the Agyghe (Cherkess) of the north Caucasus, followed by the lesser noble clans headed by murzas, and finally the kapihalk - vassals or dependents who did not originally enjoy the hereditary title of murza. ${ }^{30}$ Murza delegates provided just such a description of the Crimean elite to Governor D.B. Mertvago in 1807 in response to his request for a report on "who among the mirza clans ought to be considered beys." This, they assured him, conscious of their audience, was the architecture of what they referred to in various documents as the "Tatar nobility," "Muslim nobility" or, on occasion, simply the "Muslim estate" (magometanskoe soslovie). ${ }^{31}$

In the decades after annexation, a number of murzas served the Russian government in a civil or military capacity. For the most part however service remained an attribute of, rather than a stepping stone toward, elite status. The murzas' primary goal was to preserve the integrity of Crimean elite society and the prestige of murza status - a status patents of Russian nobility could confirm but only lineage could confer. Members of the most powerful clans thus had a stake in the process of identifying legitimate members of the "Muslim nobility" and defining the criteria for future access to the murza ranks. One 
of their primary functions was to attest to the worthiness of murzas hoping to join the ranks of the dvorianstvo. In fact, well over half of those who affixed their seals or signatures to such documents were members of the karaçi clans. Haji Ibrahim aga Emirov's 1797 petition is an excellent example. It included five firmans from Crimean khans, three Russian attestats describing the petitioner's military service, and the testimony of thirteen peers:

We the native (prirodnye) nobles of Tavrida who have affixed our signatures below out of duty and in accordance with the terms of the charter to the Russian nobility [...] do testify in regard to Ensign Emir Haji Ibrahim aga and his brothers AbdulKerim and Samadin, that before the annexation of the Crimean peninsula to the rule of the most glorious Russian state, their fathers and grandfathers served the sovereign khans. They descended from the knee of the Emirs, have not deviated from the standards expected of them by virtue of their birth, and conduct themselves in the manner of noblemen. Because of this we declare them in every way worthy of this right $[. .$.$] and in assurance of this we sign and affix our seals.$

The list of witnesses included Captain Arslanşa murza şirin, Prince Mehmetşa bey Kantakuzin, State councilor Mehmet aga Biiarslan, and senior members of the Argin, Iaşlav, and Mansur clans, all of whom had either achieved noble rank or been elected to a position of authority in the provincial administration..$^{32}$ Their testimony served as a kind of social currency within Crimea, shoring up the role of a small cluster of murzas as custodians of both the traditional and imperial social orders.

Throughout most of Russian history, lineage was a far more accurate measure of prestige and power than wealth, and genealogies were useful tools for maintaining kinship bonds (as well as the host of other interests bound up with them). They were, in the words of an historian of nobiliários in early modern Portugal, "social accreditation mechanism[s], with [their] field of action and influence expanding according to people's expectations and needs." The efficacy of such mechanisms improved dramatically when paired with antiquity of lineage and, as it did throughout the early modern world, the attraction of antiquity encouraged subjects of the tsars to indulge in occasional manipulations of the historical record. Fabrication was tolerated within certain limits, but there were narrative conventions to follow and hierarchies to respect. This was particularly so in the wake of regime change as local practices came under the scrutiny of new authority. ${ }^{33}$

The genealogies of Crimea's elite clans dated back generations, if not centuries, before the annexation of the khanate in 1783, and many boasted roots going back to the Kipchak khanate. The Giray dynasty, of course, descended from the 'white bone' - the Chingissid line that had once dominated the Eurasian steppe. The şirin clan, second in influence only to the Girays, looked back to the Volga region and a progenitor whose son, Ruktemir, was a constant companion and brother-in-law of Khan Tokhtamysh (d. 1395). The Mansurs identified their clan founder as Davidzh bey - a great chieftain in his own right, an adversary of Tokhtamysh, and the great-great-grandson of Edigey (from whom the Iusupov princes claimed descent as well). ${ }^{34}$

Murzas from lesser clans were under added pressure to compose pitch-perfect genealogies. In 1804, Abduraman Ulan-oğlu submitted a genealogy that traced the clan to no less a personage than Oğuz khan, the founder of the Hun and (through descendants) Seljuk dynasties. According to the document the family descended from the fifth son of Tiag khan, "who ruled one of the successor states of the Mogul realm when it was divided among the six sons of Oğuz." In turn, Abduraman explained, Tiag khan's sons ruled as a result of their "superior descent - unsurpassed among eastern rulers - their excellent 
physical strength and penetrating intellect." Eventually, Abduraman's direct ancestor moved westward to the Kipçak lands and from there to Crimea, where he received hereditary land grants from Sahib Giray khan (r.1532-1551). These lands passed from generation to generation until they came into the possession of Abduraman himself. ${ }^{35}$

Russian authorities did not challenge the authenticity of such claims. Because murza genealogies had to be approved by peers, there was little point claiming a lineage that either had no legitimacy or that explicitly challenged the primacy of the elite clans. This is at least part of the reason why so few murzas claimed anything more than to have descended "from an ancient noble clan." It explains why Abduraman took care to describe his ancestor as the fifth son of Tiag Khan: he was well aware of the importance of birth order, one of the three distinguishing characteristics of the typical lineage structure of Central Asian clans (along with genealogical distance and generational distance). Abduraman mitigated any potential resistance to his claim by admitting the existence of lineages superior to his own, as well as by locating the source of his blood honor beyond the borders of the Crimean-Volga tradition yet still within the prestigious geography of Turkic empires.

Others were less discerning. When the Perekop lower land court inquired in 1822 about the status of the mysterious Mengli murza Adyl-oğlu, the assembly replied that this was because, despite his claim of being a kinsman of the Krımtay clan, he was in fact merely a poor bachelor from the village of Dair whose link to the Krımtays was tenuous at best. ${ }^{36}$ The murzas showed a similarly cool response to the claims of Ignatii Vasilevich Tatarinov, formerly known as Ali Dzhangiz Giray sultan. Tatarinov had enlisted in the Russian army in 1775, retired, entered civil service and earned the rank of titular councilor in 1788. His saga, recounted in a lengthy petition submitted to the ministry of internal affairs, began with his return to Crimea from Moscow in 1794. There he found his deceased brother's wife and children "poverty stricken, the lands, gardens and other properties belonging to the clan having been both wrongly distributed to various people by the local government, and despotically appropriated by the state." ${ }^{37}$

Tatarinov's subsequent petitions reflect the intimate knowledge of the Russian system he gained working as a striapchii in the provincial courts. He grounded his arguments, however, on principles of kinship familiar to any Crimean. Upon the death of one of Tatarinov's uncles and the emigration of another, he explained, "The Giray clan's hereditary estates, which from antiquity were held in common without division, and included villages, lands and other properties in various locations throughout Crimea and Taman, passed by the right of inheritance into the possession of the third brother." This brother swore an oath of loyalty to the Russian sovereign before passing away and leaving his property to his wife, three young sons, and five daughters. Although Tatarinov declared that he wanted to restore the Giray lands to his nephews, his claim to be their uncle implied that he, the eldest surviving male, was the rightful heir. ${ }^{38}$

He would get nowhere without an accepted genealogy. But Tatarinov's incessant petitions made enemies of many of the men who had acquired the Giray lands, some of whom exercised a great deal of authority in the province. When the governor began making inquiries into the matter and found that Tatarinov could not produce a shred of evidence to back up his claims, he countered that Chingissids had never required documents to prove their descent. He was a Giray sultan, he argued, if the general public recognized him as such. ${ }^{39}$ 
37 By calling himself a Giray and playing the part with some art, he was able to convince at least a portion of the Tatar population to treat him with honor. But he had trouble winning over the elite. When officials consulted the Tavrida mufti in 1808, he claimed that he had never heard of Tatarinov or Ali Dzhangiz Giray for that matter, and the beys agreed. Tatarinov was no Giray prince and had no claim to the family's estates. Nevertheless, despite the fact that they submitted a single piece of evidence - a genealogy composed by none other than Tatarinov - the assembly recognized his nephews as legitimate sultans and "foreign" nobles. The social status of Crimeans, everyone concurred, relied not on documentation but on custom and the collective memory of peers and kin. ${ }^{40}$

\section{From Elite Integration to Ennoblement}

From the local perspective then, the process of elite integration ran against the grain of the increasingly juridical and document-based ennoblement procedures evolving everywhere from the Qing empire to Provence. ${ }^{41}$ Like their counterparts in Lithuania, Ukraine, the Caucasus, and Bessarabia, the Crimean murzas leveraged the customized privileges granted to them as new subjects (in their case in 1783) against the demands for uniformity imposed by the terms of the 1785 charter. But as more and more petitions for noble status from Greeks and Russians as well as murzas arrived in Simferopol it became clear that officials needed a definitive set of guidelines to navigate the muddy waters of exceptional circumstances, cultural differences, and imperial standards. The time had come to determine the boundaries of murza society and, more importantly, to decide whether Crimea's indigenous elite merited formal, collective ennoblement.

In early 1815 , the Senate solicited the advice of Armand Emmanuel, duc de Richelieu, the former governor-general of New Russia. The situation in Tavrida, Richelieu explained, was unique. While a smattering of Greeks were able to produce documents attesting to their noble worthiness - either from the patriarch of Constantinople or from officers of the Black Sea fleet - most Tatars offered nothing but peer testimony regarding the legitimacy of their noble lineage. Richelieu felt the government was obliged to give greater latitude to the Tatars and consider the historical and cultural differences between Russia and the "Asiatic" states, wherein members of the elite were recognized by virtue of clan affiliation rather than an accumulation of written documents. The descendants of the bey clans, high-ranking servants of the khans, and Nogay chiefs, Richelieu suggested, should be required to submit a combination of genealogies and peer testimonies - nothing more. When the Senate and State Council accepted Richelieu's proposals it seemed the Crimean and Chingissid geographies of nobility had been successfully integrated into the landscape of imperial nobility. ${ }^{42}$

On 19 August 1816, Emperor Alexander established a "commission on determining the nobility of Muslim and Greek clans" chaired by the mufti of Tavrida and staffed by representatives from the bey clans, kapihalk1, and Greeks. ${ }^{43}$ The commission worked intermittently for over a decade and, without exception, recommended everyone from Cherkess princes to low-ranking service murzas for inscription in the fourth part of the noble register - that reserved for foreign elites. Even men with exemplary military and civil service records such as Captain Kasim Argin and his brother, Court councilor Mehmetşa Argin, were registered as foreign nobles because of the fame, antiquity and honor of their clan. Ismail bey Balatukov, who petitioned for noble status on the basis of 
descent from a line of Cherkess princes, chafed when the Heraldry defined him instead as noble by virtue of his civil rank. When the Commission on Muslim and Greek clans went to work in 1820, the deputies received a petition from Ismail's son, Lieutenant Kazy bey. "Although the Heraldry ordered that my clan, along with others, be entered in the third part of the noble register," wrote Kazy, "because our ancestors descended from Cherkess princes I request examination of the distinguished evidence [to that effect] and inscription in the fourth part of the register." True to form, the commission recommended Kazy and his younger brother, Batyr, for confirmation as nobles of foreign origin. ${ }^{44}$ Thus while emperor and Senate conceived the commission as an instrument of integration and standardization, the Crimean murzas used it to formalize the distinction between them and the rest of the dvorianstvo.

41 The viability of this system died with Alexander I. In February 1828 his successor, Nicholas I, moved to re-establish oversight over the ennoblement process throughout the empire. He instructed the Senate to investigate reports of rampant abuse - the submission of falsified documents and fabricated genealogies, for example - and draft a set of corrective measures. Almost immediately the government turned its attention to Tavrida and its Muslim murzas. In 1830 Dmitrii Bludov, then acting minister of justice, initiated an inquiry into the murzas' status. "What are the rights and privileges of the murzas and upon what are they based?" he asked provincial officials. What evidence were they required to present, and what rules had the Senate applied to such cases? Most tellingly, Bludov wanted to know whether the existing rules were "sufficient to diminish the number of petitioners, or must new ones be added to account for the poor education of the Tatars and their coreligionists, as well as their practice of polygamy, which without a doubt ought to complicate the confirmation of their noble status?" ${ }^{45}$

The government's concern with the education and morality of the murzas reflected a growing unease with its predecessor's willingness to tie social and economic privileges to ethnic and cultural differences. Previous policy had allowed men like Major Seit Ibrahim aga Taşı-oğlu, a Crimean whose family had served khans and sultans for generations, to acquire Russian officer rank and secure ownership of 7,000 desiatinas of orchard, pasture and arable land. His son and grandson attained entries in the Tavrida noble register and held officer rank, but like Ibrahim felt no need to convert to Orthodox Christianity or otherwise alter their cultural identity. ${ }^{46}$

While Crimeans did not necessarily see this as a way of subverting Russian subjecthood, Nicholaevan officials drew increasingly negative conclusions from the persistence of such separate elite cultures. The rise of nationalism in the Polish and Ukrainian provinces, and the fierce resistance mounted by Muslim peoples in the north Caucasus certainly played a role, but the decision to redefine noble society was not directed against non-Russian elites per se. It was part of Nicholas's concerted effort to centralize and enhance the tsar's control over all of imperial society - something he put a premium on after the Decembrist revolt of 1825.

Thus in 1831 the Senate ordered that all noble titles be examined by special commissions, and three years later it revised the standard of evidence on which petitions for noble status could be based. 'Revision commissions' sprang up all over the empire, particularly in provinces where the Senate identified an abuse of power by the noble assembly and the confirmation of unworthy nobles. In some regions, the work of these commissions utterly transformed noble society. Some 72,000 names were struck from the registers of Podolia, Volhynia and Kiev alone, while the Olonetsk commission 
determined that almost half the ennobled families in that province were registered incorrectly. Elsewhere, the effect was muted. The review of Georgian petitions carried out in 1844 declared 25 cases false and 51 "dubious" in nature, but the vast majority (424) authentic. ${ }^{47}$

The Tavrida noble assembly stepped up its scrutiny as well. Almost immediately the provincial marshal began transferring murzas and Greeks to the second and third parts of the noble register in an effort to diminish the perception that in the former khanate prestige might derive from anything but Romanov favor. Very few murzas sensed (or reacted to) the changing tide. Captain Ali murza şirin requested that the assembly revise its decision to define him as a foreign noble and instead to ground his claim on the fact "that he received the rank of captain and possessed landed property" like any other dvorianin. But most waited for the revision commission to carry out its investigations. The commission opened in 1836 and began reviewing each and every case approved by the assembly since the compilation of the province's first noble register in 1804. The four-man commission reviewed approximately 200 cases and, like commissions throughout the empire, transferred nearly every noble inscribed in the fourth to the first, second and third parts of the register (Table 1). ${ }^{48}$

Table 1. Distribution of entries in the noble registers of Kazan and Tavrida, 1785-186049

\begin{tabular}{|l|c|c|c|c|c|c|c|}
\hline & Part 1 & Part 2 & Part 3 & Part 4 & Part 5 & Part 6 & Total \\
\hline Kazan & $10(1 \%)$ & $405(45 \%)$ & $416(46 \%)$ & $1(0 \%)$ & $4(0 \%)$ & $70(8 \%)$ & 906 \\
\hline Tavrida & $44(7 \%)$ & $262(39 \%)$ & $331(50 \%)$ & $8(1 \%)$ & $1(0 \%)$ & $22(3 \%)$ & 668 \\
\hline
\end{tabular}

Reshuffling entries in the noble registers was an essential component of the redefinition of nobility, but it was only the beginning. In March 1840, the State Council at long last announced the criteria by which the imperial government would officially judge Crimean Muslim (and Greek) claims to noble status. The Council declared that petitioners could pursue any of three strategies. They had the option of proving they or their predecessors had become Russian subjects and obtained rank through service to the tsar. Second, they could attempt to prove that they had come to Russia prior to 1805 , been recognized as a noble at the provincial level and obtained immovable property through purchase or inheritance. Muslims had the additional option of proving that they had owned their estates before 1783 and subsequently served as elected officials. Anyone who met these criteria had to prove authenticity of lineage by submitting birth and marriage documents drawn from metrical registers and a genealogy verified by the provincial marshal and close relatives whose noble status had already been confirmed. Finally, the council required each petitioner to submit the sworn testimony of the provincial marshal and twelve nobles regarding his education and lifestyle..$^{50}$

Only a handful of petitions contained this range of documentation. In fact, most applicants were born or married well before the government established metrical registers for Tavridan Muslims in 1831. The new guidelines thus stripped nearly every case of murza nobility of its validity. The Heraldry sent hundreds of previously approved petitions back to Simferopol for supplementary documentation. It cited Seitşa Ahmetov, for example, for failing to include evidence of either inheriting land owned by his family prior to 1783 or having been educated "in the proper manner." ${ }^{51}$ Er Mambet 
Dzhamin suffered disqualification because his rank as sotnik in the Crimean Tatar cavalry regiment was not equivalent to that of a regular officer. ${ }^{52}$ Even members of the bey clans could not generate sufficient evidence to satisfy the Heraldry. In 1847, Nietşa bey Iaşlav tried to convince officials of the legitimacy of his status, arguing that his was "one of the seven bey clans known by all to have descended from the ancient conquerors of Crimea and to still compose its elite." Successive khans had issued firmans confirming his forefathers' estates and testifying to their morality and prestige. Nietşa bey even composed a detailed genealogy, but his efforts were in vain. ${ }^{53}$

For all but a few exceptional cases, the 1840 State Council decision effectively ended the process of murza ennoblement in Crimea. Yet its impact was anything but local. Sixty years earlier Catherine II's decision to apply the decree on (Volga) Tatar princes and murzas to Crimea had briefly reinvented the southern steppe as a continuous landscape of Muslim Tatar elites. In subsequent years, neither the murzas nor imperial officials embraced that strategy, and elite integration followed different trajectories in various parts of the empire. By the end of 1796 for example, Paul I had confirmed more than a dozen of Orenburg's Tatar clans, while it took 40 years longer for the same number of Crimean clans to gain confirmation. Meanwhile the empire itself ceased to exist while Azerbajdzhani begs waited for the Senate to rule on their status. ${ }^{54}$ Special dispensations, procedural idiosyncrasies, gradations of all kinds - all of these created meaningful distinctions between regions and between the elite groups that inhabited them.

Now, however, the imperial government's ennoblement policies began forging (or reestablishing) linkages among non-Russian, and specifically Muslim, elites. Beginning in 1841, the Senate adapted the terms of the State Council opinion on Tavrida's Muslim and Greek clans to conditions in Orenburg and Vilna, where noble assemblies faced similar challenges from Bashkirs, Mordvinians, and Lithuanian Tatars. The government also applied the model of the commission on Muslim and Greek clans to the Caucasus, where Viceroy M.S. Vorontsov and his successor, Grand Prince Mikhail Nikolaevich, attempted to determine the complexion of the hereditary local elite. ${ }^{55}$

Meanwhile Tavridan noble society - by mid-century a hybrid of unregistered yet influential murzas and newly settled pomeshchiki - found a place in an entirely different elite geography, joining Bessarabia, Moscow, and St. Petersburg as a set of provincial elites distinguished by common socio-economic features. So few of the dvoriane of these provinces possessed the quantity of souls (100) or land (300 desiatinas) required to participate in noble assemblies that those assemblies could hardly function. Rather than allow crucial components of local administration to grind to a halt, the Senate issued a special dispensation for the nobles of these four provinces. ${ }^{56}$

51 Curating the noble soslovie, in other words, was compounded by the fact that commonalities among elites often transcended provincial, regional, even confessional boundaries. The revision commissions and Senate decisions of the 1830s and 1840s simplified matters, effectively narrowing the terms of inclusion and signaling the dvorianstvo's transformation from a potentially integrative tool into an increasingly monolithic institution. The motivations for this shift are complex, but as Stefan Berger and Aleksey Miller recently pointed out, ruling groups across nineteenth-century Europe and Eurasia were busily seeking ways "not only to limit the impact of separatist nationalism and political modernization, but also to use these new trends to strengthen empires." ${ }^{57}$ Redrawing the boundaries of noble society was one of the tools at their disposal, though it did not necessarily bring the nobility any more in line with the 
idealized image of a body of Russian-speaking Orthodox Christians who served the state and owned large quantities of land and serfs..$^{58}$

Nor was it easy to accomplish. Diversity within the noble estate derived from multiple sources: from hierarchies laid out in the Table of Ranks and the 1785 charter, from the terms of manifestos delineating new administrative and social entities, from geographically - and culturally - specific practices of nobility, and from the self-styling that was an inherent part of the production of rodoslovnye knigi. Throughout this period, the parallel processes of elite integration and empire building embedded discrete groups such as the Crimean murzas in this evolving dialogue about governance and social structure. If the eventual disaggregation of local elite status and Russian nobility formally removed murzas from the dvorianstvo, it also generated a reconsideration of the meaning of nobility that transcended the borders of Tavrida and spread out across Russia's vast imperial space.

\section{NOTES}

1. On the aims and concerns of the new imperial history see for example I. Gerasimov, S. Glebov, A. Kaplunovskii, M. Mogilner, A. Semionov, eds., Novaia imperskaia istoriia postsovetskogo prostranstva (Kazan, 2004); Jane Burbank and David Ransel, eds., Imperial Russia: New Histories for the Empire (Bloomington: Indiana University Press, 1998). The reconsideration of the soslovie system is generally associated with Gregory Freeze's influential article, "The Soslovie (Estate) Paradigm and Russian Social History," American Historical Review 92, 1 (1986): 11-36.

2. According to Andreas Kappeler, "The coalition between rulers and noble elites of both the center and periphery was one of the most important guarantees of the integrity of the premodern empire." See his "Tsentr i elity periferii v Gabsburgskoi, Rossiiskoi i Osmanskoi imperiiakh (1700-1918 gg.)," Ab Imperio 10, 2 (2007): 17-58; Idem, The Russian Empire: A Multiethnic History (New York: Longman, 2001); Aleksandr Kamenskii, "Elity Rossiiskoi imperii i mekhanizmy administrativnogo pravleniia," in Aleksei Miller, ed., Rossiiskaia imperiia v sravnitel'noi perspektive: sbornik statei (M.: Novoe izdatel'stvo, 2004), 115-139. On the general contours and characteristics of the dvorianstvo see Elise Kimerling Wirtschafter, Social Identity in Imperial Russia (DeKalb: Northern Illinois University Press, 1997); Boris Mironov, Sotsial'naia istoriia Rossii perioda imperii: XVIIInachala XX veka (SPb.:Dmitrii Bulanin, 1999).

3. Among the classic works on the dvorianstvo are M.T. Iablochkov, Istoriia dvorianskago sosloviia $v$ Rossii (SPb.: n.p., 1876); Baron S.A. Korf, Dvorianstvo i ego soslovnoe upravlenie za stoletie 1762-1855 godov (SPb.: Tipografiia Trenke i Fiusno, 1906) and A. RomanovichSlavatinskii, Dvorianstvo $v$ Rossii ot nachala XVIII veka do otmeny krepostnago prava (The Hague: Mouton, 1968). More recent case studies include (in addition to works cited elsewhere in this article) A.M. Rafikov, "Tatarskoe dvorianstvo Viatskoi gubernii na rubezhe XIX-XX vv.," Voprosy istorii, 9 (2010): 155-163; Andrei Cusco, "Estate Interest vs. State Service: The (Un)easy Integration of the Bessarabian Nobility into the Russian 
Imperial System," European Review of History 16, 1 (2009): 15-32; G.B. Azamatova, Integratsiia natsional'nogo dvorianstva $v$ rossiiskoe obshchestvo: na primere roda Tevkelevykh (Ufa: Gilem., 2008); I.R. Gabdullin, Ot sluzhilykh tatar $k$ tatarskomu dvorianstvu (M.: R.Sh. Kudashev, 2006); Mary Gembicki, "Mastering Circumstances: Power, Privilege and Self-Preservation in the Russian Provincial Administration of the Polish-Lithuanian Nobility, 1795-1812," Ph.D. dissertation, Columbia University, 2004.

4. I share an interest in shedding the language of core and periphery with the contributors to Russian Empire: Space, People, Power, 1700-1930 (Bloomington: Indiana University Press, 2007). In their introduction, editors Jane Burbank and Marc von Hagen make an eloquent pitch for thinking about imperial space more dynamically and "in more open-ended, variegated ways" (p. 22). For recent work on the noble mentalité, see Simon Dixon's review article, "Practice and Performance in the History of the Russian Nobility" in Kritika: Explorations in Russian and Eurasian History 11, 4 (2010): 763-770; and E.N. Marasinova's exposition of the importance of rank, clan, and wealth in Psikhologiia Élity rossiiskogo dvorianstva poslednei treti XVIII veka (Po materialam perepiski) (M.: Rosspen, 1999). On provincial nobilities, see Olga Glagoleva, Russkaia provintsial'naia starina: ocherki kul'tury i byta Tul'skoi gubernii (Tula: IRI “Ritm”,1993); O.V. Sizova, Dvorianstvo Iaroslavskoi gubernii $v$ kontse XVII-pervoi polovine XIX vekov (Iaroslavl', 1999); A.N. Akin'shin, Voronezhskoe dvorianstvo $v$ litsakh i sud'bakh (Voronezh, 2009).

5. On the impact of the reform see L.F. Pisar'kova, "Razvitie mestnogo samoupravleniia v Rossii do velikikh reform: obychai, povinnost", pravo," Otechestvennaia istoriia 3 (2001): 25-39; Robert D. Givens, "Eighteenth-Century Nobiliary Career Patterns and Provincial Government," in Walter McKenzie Pintner and Don Karl Rowney, eds., Russian Officialdom: The Bureaucratization of Russian Society from the Seventeenth to the Twentieth Century (Chapel Hill: University of North Carolina Press, 1980), 106-129; Marc Raeff, "The Russian Nobility in the Eighteenth and Nineteenth Centuries," in Ivo Banac and Paul Bushkovitch, eds., The Nobility in Russia and Eastern Europe (New Haven: Yale Concilium on International and Area Studies, 1983), 99-121; and chapter 2 of my doctoral dissertation, "Between Subversion and Submission: The Integration of the Crimean Khanate into the Russian Empire, 1783-1853,” Ph.D. dissertation, Harvard University, 2006.

6. Throughout this article I use the term murza to refer to any Crimean Tatar who defined himself thus to Russian authorities. Though the title belonged historically to chiefs of a finite number of clans (see below), by the eighteenth century it had been appropriated by the lesser elite as well as collateral members of each clan.

7. Tavricheskaia guberniia is generally translated as Tauride in a nod to the Greek name for the Crimean peninsula (Tauris). I prefer Tavrida not only as a more accurate transliteration of the administrative entity, but also because it captures the sense of cultural appropriation that motivated Catherine to rename the khanate. For an introduction to Russian policy see Alan Fisher, The Russian Annexation of the Crimea, 1772-1783 (Cambridge: Cambridge University Press, 1970) and The Crimean Tatars (Stanford: Hoover Institution Press, 1978).

8. This represented the vast majority of submitted petitions, DAARK (Derzhavni arkhiv v Avtonomnii Respublitsi Krym) f. 49, op. 1, d. 1014, 1. 1-30.

9. Polnoe sobranie zakonov rossiiskoi imperii, s 1649 goda [PSZ (1)], vol. 20, no.14816 (25 Nov. 1778); PSZ (1), vol. 22, no. 16187 (21 April 1785), articles 76-82; Robert Jones, The Emancipation of the Russian Nobility, 1762-1785 (Princeton: Princeton University Press, 
1993); Irina Viktorovna Faizova, "Manifest o vol'nosti" i sluzhba dvorianstva v XVIII stoletii (M.: Nauka, 1999).

10. V.M. Kabuzan and S.M. Troitskii, "Izmeneniia v chislennosti, udel'nom vese $\mathrm{i}$ razmeshchenii dvorianstva v Rossii v 1782-1858 gg.," Istoriia SSSR 4 (1971): 162-165; Kabuzan, Narodonaseleniia Rossii v XVIII-pervoi polovine XIX v. (M., 1963), tablitsa 17. The annual percentages given for the Russian empire do not include the Polish provinces.

11. Part one included those who possessed grants of noble status, coats of arms, and the like from the tsar or another monarch. Part two included those who attained officer rank; part three contained those who attained rank eight or higher through civil service or a chivalric order. Foreigners who had sworn the oath of allegiance registered in part four, titled nobles in part five, and descendants of "ancient lineages" in part six. See PSZ (1), vol. 22, no. 16187, articles 76-82.

12. Failure to follow these procedures resulted in forfeiture of the privileges described in the charter (articles 68,69). The provincial marshal and assembly deputies maintained the noble register and submitted it to the Heraldry for confirmation. The Heraldry then issued patents attesting to the noble status of each individual.

13. The Prince de Ligne. His Memoirs, Letters, and Miscellaneous Papers, vol. 2 (Boston: Hardy, Pratt \& Company, 1899), 39. On clothing regulations see O.Iu.Zakharova, Svetskie Tseremonialy $v$ Rossii XVIII - nachalo XX v. (M.: Tsentrpoligraf, 2001), 180-188; K.A. Solov 'ev, "Vo vkuse umnoi stariny...": Usadebnykh byt rossiiskogo dvorianstva (SPb.: Nestor, 1998), 27-29; Gennadii Murashev, Tituly, chiny, nagrady (SPb.: Poligon, 2002), 127-154.

14. The compilation of noble registers proved a formidable challenge to assemblies across the empire. Many nobles maintained little connection and rarely visited their provincial estates; others were reluctant to spend a tidy sum (up to 200 rubles) for a document declaring what was already common knowledge. O'Neill, "Between Subversion and Submission," chapter 4; I.V. Savitskii, Vedenie dvorianskoi rodoslovnoi knigi v Olonetskoi gubernii, 1791-1841 gg. (Petrozavodsk: Izd-vo Petrozavodskogo gos. universiteta, 2000), 9. Figure 1 is based on the Kabuzan/Troitskii data cited above.

15. RGIA (Rossiiskii gosudarstvennyi istoricheskii arkhiv), f. 994, op. 2, d. 473, 1. 1-8 (also reproduced in Arkhiv grafov Mordvinovykh, vol. 3, no. 89: 532-43).

16. PSZ (1), vol. 22, no. 15708 (8 April 1783); PSZ (1), vol. 21, no. 15798 (28 July 1783): 985-986; PSZ (1), vol. 21, no. 15861 (1 Nov. 1783): 1030-1031.

17. PSZ (1), no. 15936 (22 Feb. 1784): 51-52. The decree applied only to those whose ancestors had received pomest' $e$ from the tsars in return for service. They had been effectively removed from the nobility by the 3 November 1713 decree barring Muslims from owning enserfed peasants. This ruling was applied to Crimean murzas in June 1784. "Rasporiazheniia svetleishago kniazia Grigoriia Aleksandrovicha PotëmkinaTavricheskago kasatel'no ustroeniia Tavricheskoi oblasti s 1781 po 1786-i god," Zapiski Odesskago obshchestva istorii $i$ drevnostei, 12, 304; Said murza Enikeev, Ocherk istorii tatarskogo dvorianstva (Ufa: Gilem, 1999).

18. A total of 2,493 in Kazan, 1,008 in Saratov, 524 in Penza, 388 in Riazan, 282 in Simbirsk, 61 in Orenburg, and 55 in Nizhegorod. See Ramil' Khairutdinov, "Tatarskaia feodal'naia znat' i rossiiskoe dvorianstvo: problemy integratsii na rubezhe XVIII-XIX vv.," in Islam v Tatarskom Mire: Istoriia i sovremennost' (materialy mezhdunarodnogo simpoziuma, Kazan' 29 aprelia-1 maia 1996 g.) (Kazan, 1997), 87-90. 
19. Isabel de Madariaga, Russia in the Age of Catherine the Great (New Haven: Yale University Press, 1981), 310-312; Zenon Kohut, Russian Centralism and Ukrainian Autonomy: Imperial Absorption of the Hetmanate, 1760s-1830s (Cambridge: Harvard Ukrainian Research Institute, 1988), 238-245; Kohut, "The Ukrainian Elite in the Eighteenth Century and Its Integration into the Russian Nobility," in Banac and Bushkovitch, eds., The Nobility in Russia and Eastern Europe, 65-97.

20. RGIA, f. 1343, op. 57, d. 146, 1. 36; Iablochkov, Istoriia dvorianskago sosloviia, 583-585.

21. "O prosheniiakh deputatov Tavricheskoi oblasti na Vysochaishee Imia v 1796 godu i Vysochaishem Ukaz 17 sentiabria 1796 goda," Izvestiia Tavricheskoi uchënoi arkhivnoi komissii [ITUAK], 2: 10-11. The "Zubov decree" of September 1796 confirmed the 1794 ruling discussed below.

22. Savitskii, Vedenie Dvorianskoi rodoslovnoi knigi, 24-25; DAARK f. 327, op. 1, d. 36, 1. 1-2.

23. Iablochkov, Istoriia dvorianskago sosloviia, 515-516; Jonathan Dewald, The European Nobility 1400-1800 (Cambridge: Cambridge University Press, 1996).

24. RGIA, f. 1343, op. 57, d. 146, 1. 36; PSZ (1), vol. 23, no. 17265 (9 Nov. 1794): 585-589. On the debate over rights to own land and villages see chapter 1 of my manuscript, "Russia's Southern Empire: The Logic and Limits of Imperial Rule in Crimea" (in progress).

25. O.M. Karamyshev, "O priobretenii odnodvortsami potomstvenogo dvorianskogo dostoinstva Rossiiskoi Imperii," in O.M. Karamyshev, ed., Problemy priznaniia $i$ utverzhdeniia $v$ pravakh rossiiskogo dvorianstva vysshykh soslovii narodov Rossiiskoi Imperii i inostrannykh dvorian (SPb.: SPb-skor Dvorianskoe sobranie, 1997), 4-11.

26. I.M. Murav'ev-Apostol, Puteshestvie po Tavride v $1820 \operatorname{god}(\mathrm{SPb} ., 1823), 152$. Murav'evApostol was one of many who equated (quite mistakenly) the Tatars' disinterest in crop agriculture with indifference toward land.

27. Savitskii, Vedenie dvorianskoi rodoslovnoi knigi, 7-8.

28. F.F. Lashkov, "Istoricheskii ocherk krymsko-tatarskago zemlevladeniia," ITUAK 22: 76.

29. DAARK, f. 49, op. 1, d. 2161, 1.1.

30. Halil Inalcik, "The Khan and the Tribal Aristocracy: The Crimean Khanate Under Sahib Giray I," in Studies in Ottoman Social and Economic History (London: Varorium Reprints, 1985), 445-456; Skal'kovskii, Opyt statisticheskago opisaniia Novorossiiskago kraia, chast' 1 (Odessa: L. Nitche, 1850), 304; P.S. Pallas, Travels Through the Southern Provinces of the Russian Empire, in the Years 1793 and 1794, vol. II, (London, 1803), 352-353. Cherkess society was highly differentiated and hierarchical. At the top of the social hierarchy were the princes; the Kipçak, Kekuvat, Balatuk, Salgir and Dair clans of Crimea descended from these. See F.F. Lashkov, "Arkhivnyia dannyia o beilikakh v krymskom khanstve," Opyt iz trudov 6-go arkheologichnogo s" ezda v Odesse v 1884 g., t.4 (Odessa, 1889), 96-110.

31. Lashkov, "Arkhivnyia dannyia," 96.

32. DAARK, f. 49, op. 1, d. 5, 1. 8-9.

33. Joáo de Figueirôa-Rêgo, e-Journal of Portuguese History 6, no. 1 (2008), 2-3; Michael Confino, "À propos de la notion de service dans la noblesse russe aux XVIII et XIX $^{\mathrm{e}}$ siècles," Cahiers du Monde russe et soviétique 34, 1-2 (1993): 48; Devin DeWeese, "The Politics of Sacred Lineages in 19th-Century Central Asia: Descent Groups Linked to Khwaja Ahmad Yasavi in Shrine Documents and Genealogical Documents," Journal of Middle Eastern Studies 31 (1999): 507-530; Diana Abouali, "Family and Society in a Seventeenth-Century 
Ottoman City: The Alamis of Jerusalem," Ph.D. dissertation, Harvard University, 2003, chapter 2.

34. V. Fedorchenko, Dvorianskie rody, proslavivshie otechestvo: Entsiklopediia dvorianskikh rodov (M.: Olma-Press, 2003), 254-255, 429-430; N.A. Baskakov, Russkie familii tiurkskogo proiskhozhdeniia (M.: Mishel, 1993), 79-80, 235-236; Lashkov, "Sbornik dokumentov," ITUAK 23: 123-126; Lashkov, "Istoricheskii ocherk," 71-72; Bolenko, "Russian Grandee, European Grand Seigneur, and Tatar Prince: N.B. Iusupov: On the Question of SelfOrientalization of Russian Nobility in the Last Third of the Eighteenth - First Third of the Nineteenth Century," Ab Imperio 3 (2006): 161-216.

35. DAARK, f. 49, op. 1, d. 359, 1. 1-5.

36. DAARK, f. 49, op. 1, d. 698, 1. 1-11.

37. RGIA, f. 1341, op. 7, d. 695, 1. 101.

38. RGIA, f. 1341, op. 7, d. 695, 1. 71-72.

39. RGIA, f. 1341, op. 7, d. 695, 1. 46-48.

40. RGADA, f. 286, op. 2, d. 120, 1. 230-253.

41. Wang Feng and James Lee, "Adoption Among the Qing Nobility and its Implications for Chinese Demographic Behavior," History of the Family 3, 4 (1998): 411-428; Valérie Piétri, "Bonne renommée ou actes authentiques: la noblesse doit faire ses preuves (Provence, XVII ${ }^{\mathrm{e}}$-XVIII ${ }^{\mathrm{e}}$ siècles)," Genèses 1, 74 (2009): 5-24.

42. DAARK, f. 49, op. 1, d. 206, 1.13-15; d. 444, 1. 8-9; RGIA, f. 1343, op. 57, d. 146, 1. 2-5; DAARK, f. 27, op.1, d. 1550, 1.6. Based on Notara's report that Crimean Greeks were purchasing documents attesting to noble status from the patriarch, the Senate required them to submit proof of service to the tsar and an oath of loyalty - more stringent criteria than those applied to the Tatars.

43. RGIA, f. 1343, op. 57, d. 146, 1. 2-5. Similar commissions were established in Bessarabia (1818-1821) and the Caucasus. See Matei Cazacu, "Familles de la noblesse roumaine au service de la Russie, $\mathrm{XV}^{\mathrm{e}}$-XIX ${ }^{\mathrm{e}}$ siècles," Cahiers du Monde russe et soviétique 34, 1-2 (1993): 211-226.

44. DAARK, f. 49, op. 1, d. 607, 1. 32; d. 1409, 1. 9-10; d. 1975, 1. 7-18, 29-32. Ismail bey had attained officer rank, retired, and won election to a succession of posts in Simferopol district between 1791 and 1820 .

45. RGIA, f. 1343, op. 57, d. 146, 1. 1; d. 64, 1. 157-164.

46. DAARK, f. 49, op. 1, d. 5, 1. 1-9; d. 6493, 1. 1-15.

47. Savitskii, Vedenie dvorianskoi rodoslovnoi knigi, 26; Iablochkov, Istoriia dvorianskago sosloviia, 618 .

48. DAARK, f. 49, op. 1, d. 6620, 1. 1-24; d. 6621, 1. 1-15; d. 6626, 1. 1-36; V.I. Solov'ev, Russkoe dvorianstvo $i$ ego vydaiushchiesia predstaviteli (Rostov-na-Donu: Feniks, 2000), 120-121. The assembly had approved far more than 200 cases, but the resources of the commission were limited.

49. The Kazan data is drawn from G.A.Dvoenosovoa, G.N.Vul'fson, Dvorianskaia Rodoslovnaia Kniga Kazanskoi gubernii 1785-1917 gg. (Kazan: Kazanskii gos. ènergeticheskii universitet, 2004), 50. I compiled the Tavrida data from the rodoslovnye knigi held at RGIA, f. 1343, op. 51, d. 485-496, and the composite list in delo 664. 
50. PSZ (2), vol. 15, no. 13304 (27 March 1840), “o pravakh zhivushchikh v Rossii Grekov i Magometan na dvorianskoe dostoinstvo"; DAARK, f. 49, op. 1, d. 1617, 1. 1-5.

51. DAARK, f. 49, op. 1, d. 1078, 1. 33.

52. DAARK, f. 49, op. 1, d. 1591, 1. 20-21.

53. DAARK, f. 49, op. 1, d. 2161, 1. 1-2, 37-40, 132.

54. Iablochkov, Istoriia dvorianskago sosloviia, 617-618; Kappeler, The Russian Empire, 176-177.

55. Regarding Orenburg's Muslim elite see RGIA, f. 1343, op. 57, d. 206, 1.1-21; d. 213, 1.1-10, 23. On Lithuanian Tatars, see RGIA, f. 1343, op. 57, d. 224, 1.1-10; A.V. Krasko, "K voprosu o soslovnykh pravakh i soslovnoi organizatsii khanov, bekov, agalarov i melikov v Rossiiskoi Imperii," in Problemy priznaniia, 18-21.

56. Such nobles needed only to possess a house and land, settled or unsettled, from which they derived no less than 2,000 rubles annually in order to participate in assembly elections and be elected themselves. The decisions came out in a set of decrees issued between 6 December 1831 and 17 January 1833. See Iablochkov, Istoriia dvorianskago sosloviia, 632-633.

57. Stefan Berger and Aleksey Miller, "Nation-Building and Regional Integration, c. 1800-1914: The Role of Empires," European Review of History 15, 3 (2008): 318.

58. The accumulation of imperial legislation certainly created a curious profile in Tavrida, where by 1842 murzas constituted less than 30 percent of registered nobles. Sixty-one percent of those murzas owned sufficient land to meet the original criteria for participation in the assembly however, while only 12 percent of Russian nobles could say the same. The district registers are in DAARK, f. 49, op. 1, d. 1712, 1.1-49ob.

\section{ABSTRACTS}

Abstract

In tsarist Russia, elite integration was a crucial component of empire building. While the status claimed by, or ascribed to, non-Russian elites helped determine the relationship between core and periphery, elite integration had an equally important latitudinal dimension. Careful study of the nuances of this process in Tavrida province (the former Crimean khanate) suggests that the ennoblement of borderland figures engendered a reconceptualization of the implications and accessibility of noble status throughout the empire. The case of the Crimean murzas, explored in this article, suggests that we rethink the geography of social categories and the dynamics of the process through which officials and elites curated noble society in the late eighteenth and early nineteenth centuries. The murzas were a diminutive population - never more than 500 at a given time - but they were Muslims in an era of religious toleration, former vassals of the sultan in the age of Russian-Ottoman rivalry, and heirs to steppe traditions in the midst of Russia's attempt to reinvent herself as a European state. Determining whether and how a murza might become a nobleman therefore had wide-ranging logistical and ideological implications for imperial society. 
Résumé

Dans la Russie tsariste, l'intégration des élites était une composante cruciale de l'édification de l'empire. Alors que les statuts auxquels prétendaient les élites non russes, ou qui leur étaient attribués, aidaient à déterminer la relation entre le centre et la périphérie, l'intégration des élites revêtait une dimension latitudinale non moins importante. Une étude attentive des nuances de ce processus dans la province de Tauride (l'ex-khanat de Crimée) suggère que l'anoblissement des personnages importants des régions limitrophes engendrait une reconceptualisation des implications et de l'accessibilité au statut de noble dans tout l'Empire. Le cas étudié dans cet article, celui des mourzas de Crimée, propose de repenser la géographie des catégories sociales et les dynamiques du processus par lequel les officiels et les élites organisaient la société noble à la fin $d u x \mathrm{XIII}^{\mathrm{e}}$ et au tout début du XIX ${ }^{\mathrm{e}}$ siècle. Les mourzas formaient un groupe de population très peu nombreux - jamais plus de cinq cents individus à une époque donnée - mais ils étaient musulmans dans une période de tolérance religieuse, anciens vassaux du sultan à l'époque de la rivalité russo-ottomane et héritiers des traditions de la steppe alors que la Russie tentait de se réinventer comme un État européen. De ce fait, déterminer si et comment un mourza pouvait être anobli avait des implications idéologiques et logistiques très diverses pour la société impériale.

\section{AUTHOR}

\section{KELLY O'NEILL}

Harvard University, History Department 